А. С. Горны

Гродзенскі дзяржаўны ўніверсітэт імя Янкі Купалы

\title{
БЕЛАРУСКІ СЯЛЯНСКІ САЮЗ Ў МІЖВАЕННАЙ ЗАХОДНЯЙ БЕЛАРУСІ: СТРУКТУРА І ДЗЕЙНАСЦЬ
}

У артыкуле на аснове здабыткаў айчынай і замежнай гістарыяграфіi, апублікаваных і архіўных крыніц аналізуецца дзейнасць малавядомай палітычнай структуры ў міжваеннай Заходняй Беларусі - Беларускага сялянскага саюза. Аўтар разглядае дзейнасць гэтай арганізацыі ў кантэксце агульнаеўрапейскіх працэсаў росквіту аграрных партый і ідэалогіi аграрызму ў міжваенны перыяд. Беларускі сялянскі саюз быў утвораны ў 1925 г. у выніку расколу ў Беларускім пасольскім клубе. Арганізацыя аб'ядноўвала вакол сябе прыхільнікаў нацыянальна-дэмакратычнай плыні беларускага руху і разглядалася як альтэрнатыва леварадыкальнай Беларускай сялянска-работніцкай грамадзе. Эканамічны блок праграмы Беларускага сялянскага саюза меў дастаткова левы накірунак, аднак у палітычным плане партыя выступала за ўтварэнне незалежнай беларускай дзяржавы па ўзоры Беларускай народнай рэспублікі. У артыкуле таксама раскрываюцца магчымы колькасны склад партыі, геаграфічны арэал яе дзейнасці, тыя асноўныя палітычныя праекты, у якіх актывісты партыі прынялі значны ўдзел.

У заключэнні робіцца выснова, што Беларускі сялянскі саюз меў дастаткова сціплую колькасць сваіх прыхільнікаў, нягледзячы на арыентацыю ў сялянскае асяроддзе Заходняй Беларусі. Партыя не змагла канкурыраваць 3 разгалінаванай сеткай актывістаў Беларускай сялянскаработніцкай грамады і яе леварадыкальнай рыторыкай.

Ключавыя словы: Заходняя Беларусь, Польшча, міжваенны перыяд, беларускі нацыянальны рух, палітычная партыя, Беларускі сялянскі саюз.

Для цытавання: Горны А. С. Беларускі сялянскі саюз ў міжваеннай Заходняй Беларусі: структура і дзейнасць // Труды БГТУ. Сер. 6, История, философия. 2021. № 1 (245). С. 79-84.

\section{A. S. Gorny \\ Yanka Kupala State University of Grodno \\ THE BELARUSIAN PEASANTS' UNION \\ IN THE INTERWAR WESTERN BELARUS: STRUCTURE AND ACTIVITY}

The article analyzes the activities of a little-known political structure in interwar Western Belarus the Belarusian Peasants' Union, based on the achievements of domestic and foreign historiography, archival sources. The author considers the activities of this organization in the context of European processes of prosperity of agrarian parties and the ideology of agrarianism in the interwar period. The Union was formed in 1925 as a result of a split in the Belarusian Deputates' Club. The organization united supporters of the national-democracy current of the Belarusian movement and was seen as an alternative to the left-wing Belarusian Peasants' and Workers' Hramada. The economic bloc of the program of the Belarusian Peasants' and Workers' Union was left-wing political spectrum, but stand up for the formation of an independent Belarusian state on the model of the Belarusian People's Republic. The article reveals the possible number of its members, the geographical area of its activities, the main political projects in which party activists took a significant part.

In conclusion, it is concluded that the Belarusian Peasants' Union had a small number of supporters, despite the orientation to the peasant environment of Western Belarus. The Union could not compete with the branched structure of activists of the Belarusian Peasants' and Workers' Hramada and its left-wing political spectrum.

Key words: Western Belarus, Poland, the interwar period, the Belarusian national movement, the political party, the Belarusian Peasants' Union.

For citation: Gorny A. S. The Belarusian Peasants' Union in the interwar Western Belarus: structure and activity. Proceedings of BSTU, issue 6, History, Philosophy, 2021, no. 1 (245), pp. 79-84 (In Belarusian).

Уводзіны. Беларускі сялянскі саюз (БСС) у гісторыі Заходняй Беларусі міжваеннага перыяду - сапраўднае terra incognita, нягледзячы на дастаткова добрую распрацаванасць праблемы партыйнай гісторыі ў гэты перыяд. На сённяшні час у беларускай гістарыяграфіi ўвогуле няма асобнага даследавання, прысвечанага дзейнасці гэтай палітычнай структуры. 
Дадзены артыкул - першая спроба комплексна асэнсаваць ролю БСС у грамадска-палітычным жыцці міжваеннай Заходняй Беларусі і вызначыць ступень яго ўплыву на беларускае насельніцтва тагачаснай Польшчы.

У савецкім гістарычным дыскурсе БСС як нацыянальна-дэмакратычная i «непралетарская» арганізацыя мела апрыёры негатыўную ацэнку. Пачатак такога стаўлення можна знайсці ўжо ў аналітычных працах аб грамадскапалітычным жыцці Заходняй Беларусі, якія выходзілі ў БССР у міжваенны перыяд. У прыватнасці, савецкі беларускі публіцыст Сянкевіч А. у 1928 г. называў БСС «арганізацыяй з чыста кулацкім тварам» $[1$, с. 16]. Падобныя негатыўныя характарыстыкі перайшлі і ў пасляваенную савецкую гістарыяграфію па гісторыі Заходняй Беларусі, дзе асноўная ўвага надавалася леварадыкальным палітычным сілам [2, с. 107]. Той факт, што арганізацыя дастаткова паслядоўна крытыкавала палітыку польскіх улад у Заходняй Беларусі, а некаторыя 3 яе актывістаў пераследваліся гэтымі ўладамі, цалкам ігнараваўся савецкімі гісторыкамі. Адным з галоўных пунктаў крытыкі была «аграрная» сутнасць партыі, якая не адпавядала некаторым «пралетарскім» прынцыпам марксізму-ленінізму.

Адным 3 першых гісторыкаў, хто паспрабаваў аб'ектыўна ахарактарызаваць дзейнасць БСС, быў польскі даследчык Ежы Хольцер. У манаграфіi «Палітычная мазаіка Другой Рэчы Паспалітай», выдадзенай ў 1974 г. у сацыялістычнай Польшчы, аўтар, нягледзячы на марксісцкую метадалогію, указаў на падабенства БСС да іншых еўрапейскіх сялянскіх партый, падкрэсліў яго апазіцыйнасць да польскіх улад і вызначыў некаторыя агульныя рысы праграмы саюза 3 праграмай Беларускай сялянска-работніцкай грамады (БСРГ) [3, s. 260]. У працах сучасных беларускіх і замежных даследчыкаў БСС разглядаецца толькі фрагментарна, у агульным кантэксце дзейнасці беларускіх палітычных арганізацый міжваеннай Польшчы або ўвогуле ігнаруецца [4, s. 84].

Асноўная частка. Міжваеннае дваццацігоддзе было перыядам росквіту дзейнасці аграрных партый у Цэнтральна-Усходняй Еўропе i ідэалогіi аграрызму ў цэлым. Правядзенне шырокіх аграрных рэформ у гэтым рэгіёне, распад трох імперый пасля Першай сусветнай вайны выклікалі неабходнасць інтэграцыі сялянства ў сферу палітычнага жыцця і спалучэння нацыянальных, дэмакратычных інстытутаў з патрабаваннямі вёскі. Таму ад Эстоніi да Югаславіі сялянскія партыі ў міжваенны перыяд сталі часткай урадавых кааліцый ці адыгрывалі істотную ролю ў дзяржаўнай палітыцы. Паводле гісторыкаў Мюлера Д. і Харр А., сялянская ідэалогія ў Цэнтральна-Усходняй Еўропе ўяўляла сабой своеасаблівы «трэці шлях» паміж нарастаючым фашызмам і калектывізмам у выглядзе камуністычнай дактрыны. Пры гэтым прадстаўнікі аграрызму не былі простымі рамантыкамі-традыцыяналістамі. Яны выступалі за захаванне вёскі і сялянскай сям'і як важнага элемента нацыянальнай будучыні i дзяржаўнай структуры, папярэджвалі грамадства аб небяспецы татальнай урбанізацыі, бачылі эканамічную перавагу ў захаванні прыватнай ўласнасці і пашырэнні кааператыўнай вытворчасці [5, p. 8-9]. 3 агульнаеўрапейскімі працэсамі таго часу была звязана і заходнебеларуская вёска, дзе ідэалогія аграрызму таксама знаходзіла сваіх прыхільнікаў.

Утварэнне БСС стала магчымым дзякуючы расколу, які адбыўся ў беларускай фракцыі польскага парламента (Беларускі пасольскі клуб) у чэрвені 1925 г. У гэты перыяд 3 клуба выйшлі 4 дэпутаты - Тарашкевіч Б., Рак-Міхайлоўскі С., Мятла П., Валошын П., якія ўтварылі асобную пасольскую фракцыю - Беларускую сялянска-работніцкую грамаду. Дадзеная фракцыя прытрымлівалася леварадыкальнай ідэалогіі ў сваёй дзейнасці і дзеля гэтага мела моцную падтрымку з боку савецкіх структур. У 1926 г. на аснове фракцыі пачалося фарміраванне партыйнай сеткі БСРГ у Заходняй Беларусі [4, s. 82]. Частка дэпутатаў Беларускага пасольскага клуба, у прыватнасці Ярэміч Ф. і Рагуля В., якія былі нязгодныя на збліжэнне 3 камуністамі, вырашылі ўтварыць уласны палітычны праект цэнтрысцкай арыентацыі. Такім чынам, у лістападзе 1925 г. узнікла арганізацыя Беларускі сялянскі саюз, якая разглядалася ў шмат чым як альтэрнатыва прасавецкаму БСРГ [6, с. 277].

Спачатку дзейнасць новай структуры была накіравана на пошук патэнцыйных саюзнікаў у барацьбе 3 прадстаўнікамі леварадыкальнай плыні беларускага нацыянальнага руху ў Польшчы. У прыватнасці, у студзені 1926 г. была заключана дамова 3 лідарам беларускіх хрысціянскіх дэмакратаў кс. Станкевічам А. [6, с. 279]. Былі ўстаноўлены кантакты 3 прадстаўнікамі беларускай эміграцыі, у першую чаргу $з$ беларускімі эсэрамі і дзеячамі БНР у Празе. Паступова вакол БСС фарміраваўся адзін з першых антыкамуністычных беларускіх блокаў у міжваеннай Заходняй Беларусі, які прэтэндаваў на значнае месца ў грамадскапалітычным жыцці і арыентаваўся на парламенцкія формы дзейнасці. Каб мець моцны інфармацыйны фон, у снежні 1925 г. пачаў выходзіць друкаваны орган БСС - газета «Сялянская Ніва». У першым рэдакцыйным артыкуле былі падкрэслены не толькі памкненні падтрымліваць аграрызм у беларускім грамадстве, 
але і ў завуаліяванай форме незалежніцкія погляды [7].

Каб канчаткова выбудаваць сваю арганізацыйную структуру, лідары БСС 24 сакавіка 1926 г. арганізавалі ў Вільні канферэнцыю сваіх прыхільнікаў, якая павінна была адыгрываць ролю «ўстановачнай» партыйнай канферэнцыі. На мерапрыемстве прысутнічалі 24 удзельнікі 3 розных заходнебеларускіх мясцовасцей. Пасля дакладаў В. Рагулі аб зямельным пытанні і Ф. Ярэміча аб палітычнай сітуацыі былі абраны сталыя кіраўнічыя органы арганізацыі. У Цэнтральны камітэт БСС увайшлі В. Рагуля (старшыня), Ф. Ярэміч (віцэ-старшыня), І. Куніцкі (віцэ-старшыня), А. Більдзюкевіч (сакратар), Б. Туронак (сакратар) [8]. Акрамя выбараў кіраўніцтва, яшчэ адным пытаннем, што стаяла на парадку дня віленскай канферэнцыі, была распрацоўка партыйнай праграмы i арганізацыйнага статута БСС. Пасля непрацяглай дыскусіі абодва дакумента былі прынятыя большасцю прысутных [9].

У сваёй праграме БСС выразна пазіцыянаваў сябе як нацыянальна-дэмакратычную партыю 3 аграрнай ідэалогіяй. У рамках дзяржаўнага будаўніцтва саюз выступаў за незалежнасць аб'яднаных беларускіх зямель, не адмаўляючыся пры гэтым ад гіпатэтычнай федэрацыі 3 суседнімі народамі $[10$, с. 1]. Падобны пункт праграмы вельмі цесна збліжаў арганізацыю 3 БХД і іншымі беларускімі нацыянальна-дэмакратычнымі структурамі ў Заходняй Беларусі.

Адным 3 галоўных праграмных пастулатаў БСС была абарона інтарэсаў сялянства як дамінуючай часткі беларускага насельніцтва. Прадстаўнікі партыі сыходзілі $з$ той думкі, што каля 90\% беларусаў складаюць сяляне, якія практычна ніяк не прадстаўлены ў грамадскім жыцці, у адрозненне, напрыклад, ад рабочых. Апошнія, паводле праграмы БСС, маюць у гарадах свае прафесійныя саюзы, сацыялістычныя партыі, якія забяспечваюць абарону іх сацыяльных і палітычных інтарэсаў $[10$, с. 8]. У гэтым плане праграма БСС значна разыходзілася 3 праграмнымі ўстаноўкамі БСРГ ці іншых леварадыкальных арганізацый Заходняй Беларусі, якія прытрымліваліся ленінскіх поглядаў на саюз сялян і рабочых у барацьбе з капіталізмам. Калі БСС бачыла сябе выключна як сялянскую партыю, то БСРГ імкнулася дзейнічаць не толькі ў сялянскім асяроддзі, але выходзіць і на гарадскі ўзровень. Разам 3 гэтым у тагачасных гарадах міжваеннай Польшчы палітычны рэй вялі агульнапольскія і яўрэйскія палітычныя партыі, што прымушала некаторыя беларускія левыя структуры «вяртацца» ў вясковую мясцовасць. Парадаксальна, але БСС і БСРГ крытыкавалі адзін аднаго за ідэалагічныя разыхо- джанні наконт рабочых, аднак абедзве партыі дзейнічалі ў адным і тым жа сялянскім асяроддзі. У цэлым праграма БСС па шмат якіх пунктах адпавядала праграме БСРГ. У ёй прысутнічалі патрабаванні перадзелу абшарніцкіх, дзяржаўных, царкоўных зямель і перадачы іх сялянам без выкупу, скасавання асадніцтва, перадачы лясных зямель і прыродных багаццяў у карыстанне беларускага насельніцтва, аддзялення рэлігіі ад дзяржавы і інш. [10, с. 1-7].

На «ўстаноўчай» канферэнцыі 24 сакавіка 1926 г. быў таксама зацверджаны статут партыі, у якім быў распрацаваны яе арганізацыйны лад. Нізавой структурнай адзінкай БСС лічыўся гурток, які складаўся мінімум 3 трох сяброў партыі. Некалькі гурткоў на пэўнай тэрыторыі аб'ядноўваюцца і ствараюць акружны партыйны камітэт. На з'ездзе акружных камітэтаў было прадугледжана ўтварыць Цэнтральны камітэт БСС з сямі чалавек. Вышэйшым партыйным органам кіраўціцтва лічыўся Кангрэс, які павінен быў праходзіць штогод. На справе, аднак, уся гэтая структура не функцыянавала ў поўным аб'ёме - за ўвесь перыяд дзейнасці партыі, напрыклад, так і не быў скліканы Кангрэс БСС або з'езд акружных камітэтаў [10, с. 9-16].

Найвышэйшай формай арганізацыйнай дзейнасці БСС былі толькі партыйныя канферэнцыі, якіх за ўвесь перыяд існавання партыі адбылося ўсяго дзве. Другая партыйная канферэнцыя была арганізавана 24 ліпеня 1927 г. у Вільні. На ёй прысутнічалі 27 актывістаў з розных паветаў Заходняй Беларусі. На мерапрыемстве быў пераабраны Цэнтральны камітэт арганізацыі, які стаў складацца 3 наступных асоб: В. Рагуля (старшыня), Ф. Ярэміч (віцэ-старшыня), К. Юхневіч (віцэ-старшыня), А. Більдзюкевіч (сакратар), Б. Туронак (сакратар). Былі прыняты рэзалюцыі па палітычным, зямельным і асветніцкім пытаннях, дзе, сярод іншага, партыя падкрэслівала сваю апазіцыйнасць да існуючага польскага ўраду [11, с. 2].

Адной $з$ першых значных палітычных кампаній, у якой прыняў удзел БСС, былі выбары ў органы мясцовага самакіравання 1927 г. Кіраўніцтва партыі арганізавала выбарчую кампанію ў двух значных гарадскіх асяродках Заходняй Беларусі - Вільні і Гродна. Была зроблена стаўка на перамовы 3 іншымі нацыянальнымі меншасцямі і у выніку БСС змагло знайсці паразуменне толькі з рускімі. У прыватнасці, у Вільні 22 мая 1927 г. быў створаны аб'яднаны руска-беларускі выбарчы камітэт, у якімі дзейнічалі актывісты БСС Ярэміч Ф. і Більдзюкевіч А. [12, арк. 53]. Падобная стратэгія была рэалізавана і ў Гродна: там таксама быў утвораны аб'яднаны руска-беларускі блок, а на першым месцы ў выбарчым спісе блока 
стаяў прыхільнік БСС настаўнік Федарук У. Тым не менш вынікі выбараў для партыі аказаліся больш чым сціплыя. У Вільні агульнымі намаганнямі руска-беларускі камітэт правёў у гарадскую Раду толькі аднаго дэпутата, а па ўсім Віленскім ваяводстве ў органы самакіравання прайшлі 10 прыхільнікаў БСС [13].

Другой палітычнай кампаніяй, у якой БСС прыняў значны ўдзел, былі парламенцкія выбары ў Польшчы ў 1928 г. Адзін 3 лідараў партыі Ярэміч Ф. прапанаваў утварыць адзіны беларускі выбарчы фронт, аднак цэнтрабежніцкія тэндэнцыі ў беларускім руху на той час былі настолькі моцнымі, што гэтая ідэя не атрымала падтрымкі. На заклік Ярэміча адгукнуліся толькі ідэалагічна блізкія да БСС арганізацыі: БХД і Праваслаўнае беларускае дэмакратычнае аб'яднанне на чале 3 В. Багдановічам. У снежні 1927 г. яны ўтварылі Беларускі цэнтральны аб'яднаны выбарчы камітэт, які неўзабаве пачаў весці перамовы 3 іншымі нацыянальнымі меншасцямі Польшчы. У выніку быў утвораны Блок нацыянальных меншасцей, куды, акрамя беларусаў, увайшлі прадстаўнікі некаторых украінскіх, нямецкіх і яўрэйскіх арганізацый. Дзякуючы добрай агітацыйнай кампаніi, удзел у блоку дапамог БСС правесці ў польскі парламент 3 сваіх сяброў: у сейм Ф. Ярэміча і К. Юхневіча, у сенат - В. Рагулю [14, с. 71, 72, 79].

Асобным аспектам гісторыі Беларускага сялянскага саюза 3'яўляецца вызначэнне колькасці яго актыву i прыхільнікаў. Фактычна можна абапірацца толькі на другасныя даныя, якія дазваляюць скласці, прынамсі, прыблізную карціну колькаснага складу БСС у 1920-я гг. Так, у ліпені 1927 г. на канферэнцыі БСС прысутнічалі 27 удзельнікаў: 5 - з Вільні, 22 - 3 розных паветаў Заходняй Беларусі [11, с. 1]. Падчас муніцыпальных выбараў 1927 г. кіраўніцтва БСС разлічвала прыцягнуць да выбарчых урнаў у Вільні каля 100 сваіх прыхільнікаў [12, арк. 53]. Увогуле ў 1927 г. колькасць сяброў партыі павялічылася за кошт пераходу ў структуры БСС былых актывістаў БСРГ. Пасля ліквідацыі Грамады польскімі ўладамі частка яе сяброў хутка далучылася да легальных беларускіх арганізацый, каб пазбегнуць пераследавання 3 боку паліцы [15, арк. 1]. У цэлым тэарэтычна можна вызначыць, што колькасць партыйнага актыву БСС у Заходняй Беларусі магла даходзіць да 100 чалавек, агульная колькасць сябраў партыі магла дасягаць лічбы 1000 чалавек. Яшчэ каля 1000 чалавек з'яўляліся пасіўнымі прыхільнікамі БСС - уся іх прыхільнасць выяўлялася ў выпісванні і распаўсюджванні партыйнай газеты «Сялянская ніва».

Цяжка таксама вызначыць тыя мясцовасці ў Заходняй Беларусі, дзе БСС стварала сталыя ачагі сваёй актыўнасці. Ёсць сведчанні, што пэўны асяродак прыхільнікаў парты быў у Браслаўскім павеце, дзе нават існаваў акружны камітэт БСС на чале з беларускім актывістам i дэпутатам польскага сейма ў 1928-1930 гг. К. Юхневічам [16, с. 214]. Як узгадвалася вышэй, каля 10 прадстаўнікоў БСС прайшлі ў органы мясцовага самакіравання ў Дзісненскім павеце падчас выбараў 1927 г. [13]. Значны асяродак прыхільнікаў БСС сфарміраваўся ў Нягневіцкай гміне Навагрудскага павета, дзе праводзіў частыя агітацыйныя кампаніi старшыня партыі Рагуля В. [17].

Крытыка, якой падвяргаўся БСС 3 розных бакоў, а таксама немагчымасць лідараў партыі выпрацаваць моцныя рухавікі кіравання партыйнымі структурамі, выклікалі ўнутраныя супярэчнасці i цэнтрабежніцкія тэндэнцыі. У прыватнасці, у чэрвені 1927 г. у БСС адбыўся раскол і з яго складу выйшла частка дзеячаў на чале 3 доктарам філалогіi Я. Станкевічам. Неўзабаве была ўтворана новая палітычная структура 3 той жа самай назвай - Беларускі сялянскі саюз (пасля - Беларуская сялянская партыя), на чале якой знаходзіўся Часовы камітэт пад кіраўніцтвам Я. Станкевіча [18, s. 284]. У праграмным плане гэтая партыя цалкам імкнулася адпавядаць ідэалагічным устаноўкам былых беларускіх эсэраў з іх левым радыкалізмам, але насамрэч ёй належала дастаткова маргінальнае месца на палітычнай сцэне Заходняй Беларусі, займалася фактычна толькі выданнем сваёй газеты «Народ». Аднак дзякуючы польскім паліцэйскім крыніцам можна ўсталяваць, што за расколам у БСС стаяла іншая асоба - Антон Луцкевіч. Ён лічыў аднымі са сваіх галоўных палітычных апанентаў Ф. Ярэміча і В. Рагулю, таму і рабіў захады па расколу іх арганізацыі. Выхад групы Станкевіча быў ні чым іншым як добра падрыхтаванай акцыяй пад кіраўніцтвам Луцкевіча [19, арк. 44].

Істотнымі праблемамі у дзейнасці БСС, якія ўрэшце i прывялі да заняпаду партыі, былі адсутнасць сталых фінансавых сродкаў і немагчымасць кіраўніцтва партыі выбудаваць моцную арганізацыйную структуру згодна са статутам. Заходнебеларуская вёска была разагітавана структурамі БСРГ або камуністамі і леварадыкальная рыторыка набывала першае месца ў заходнебеларускім палітычным дыскурсе. Фінансаванне арганізацыі, якое складалася 3 асабістых ахвяраваняў лідараў партыі - дэпутатаў польскага сейма Ярэміча Ф. і Рагулі В., было адносна невялікім, бо яго хапала фактычна толькі на выданне партыйнай газеты «Сялянская ніва» [20, арк. 53]. У канцы 1920-х гг. БСС як палітычная арганізацыя паступова 
знікла $з$ палітычнай сцэны Заходняй Беларусі, аднак афіцыйнай інфармацыі аб яе ліквідацыі пакуль не выяўлена.

Заключэнне. Такім чынам, у 1925-1929 гг. у Заходняй Беларусі дзейнічала палітычная партыя Беларускі сялянскі саюз, якая ўзнікла ў кантэксце еўрапейскіх працэсаў развіцця аграрызму і аграрнай ідэалогіi ў міжваенны перыяд. Таксама яна разглядалася як альтэрнатыва прасавецкай БСРГ, якая з 1926 г. пачала рабіцца найбольш масавай палітычнай сілай у заходнебеларускай вёсцы. Нягледзячы на некаторыя падабенствы праграмы, БСС займаў прынцыповую антыкамуністычную пазіцыю і агітаваў за стварэнне незалежнай беларускай дзяржавы, што набліжала яго да іншых арганізацый нацыянальна-дэмакратычнай плыні беларускага нацыянальнага руху. За перыяд свайго існавання саюз меў дастаткова сціплую колькасць сваіх прыхільнікаў, нягледзячы на арыентацыю ў сялянскае асяроддзе, якое ў міжваенны перыяд у Заходняй Беларусі вылучалася сваёй палітызаванасцю. Арганізацыя не змагла ў палітычнай гонцы абысці БСРГ і яе леварадыкальны дыскурс, які быў вельмі прыхільна сустрэты ў заходнебеларускай вёсцы, што прывяло да паступовага яе заняпаду. Адсутнасць сталай крыніцы фінансавання паставіла канчатковую кропку ў гісторы Беларускага сялянскага саюза.

\section{Спіс літаратуры}

1. Сянкевіч А. Палітычныя групоўкі ў Заходняй Беларусі перад выбарамі ў Польскі сойм // Бальшавік Беларусі. 1928. № 1. С. 15-19.

2. Полуян В., Полуян И. Революционное и национально-освободительное движение в Западной Белоруссии в 1920-1939 гг. Минск: Госиздат БССР, 1962. 224 с.

3. Holzer J. Mozaika polityczna Drugiej Rzeczypospolitej. Warszawa: Książka i Wiedza, 1974. 664 s.

4. Gomółka K. Białorusini w II Rzeczypospolitej // Zeszyty naukowe Politechniki Gdańskiej. Ekonomia. 1992. Nr. XXXI. S. 3-179.

5. Muller D., Harre A. Introduction: Agrarianism as Third Way // Transforming rural societies / ed.: Dietmar Muller, Angela Harre. Innsbruck: Studienverlag, 2011. P. 7-13.

6. Кароткі нарыс беларускага пытаньня. Мінск: Логвінаў, 2009. 396 с.

7. Ад рэдакцыі // Сялянская ніва. 1925. № 1. С. 1.

8. 3 арганізацыйнага жыцьця Беларускага сялянскага саюза // Сялянская ніва. 1926. № 11. С. 2.

9. Більдзюкевіч А. Конфэрэнцыя Беларага сялянскага саюза // Сялянская ніва. 1926. № 14. С. 2.

10. Праграма і статут Беларускага сялянскага саюза. Вільня: Друкарня Н. Левіна, 1926. 16 с.

11. Справаздача 3 канфэрэнцыі Беларускага сялянскага саюза // Сялянская ніва. 1927. № 58. C. $1-2$.

12. Lietuvos centrinis valstybès archyvas (LCVA). F. 15. Ap. 2. B. 386.

13. Разгром польскай палітыкі ў Заходняй Беларусі (вынікі выбараў у Віленскім ваяводзтве) // Савецкая Беларусь. 1927. № 183. С. 2.

14. Пашкевіч А. В. Парламенцкія формы змагання за нацыянальныя і сацыяльныя правы беларускага народа ў міжваеннай Польшчы (1921-1930 гг.): дыс. ... канд. гіст. навук: 07.00.02. Мінск, 2006. $162 \mathrm{c.}$

15. Дзяржаўны архіў Гродзенскай вобласці (ДАГВ). Ф. 551. Воп. 1. Спр. 1028.

16. Базарэвіч Г. Х. Беларускі культурна-асветніцкі рух на Браслаўшчыне ў 1925-1930 гг. // Браслаўскія чытанні / навук. рэд. В. М. Ляўко. Мінск: Беларуская навука, 2016. С. 208-217.

17. Наднёманец. Дзеяч Сялянскага саюза // Наш голас. 1927. № 3. С. 4.

18. Białorusini // Sprawy Narodowościowe. 1927. Nr. 3. S. 283-288.

19. LCVA. F. 53. Ap. 23. B. 1784.

20. Дзяржаўны архіў Брэсцкай вобласці (ДАБВ). Ф. 67. Воп. 1. Спр. 1232.

\section{References}

1. Siankievich A. Political groups in Western Belarus before the elections to the Polish Sejm. Bal'shavik Belarusi [The Bolshevik of Belarus], 1928, no. 1, pp. 15-19 (In Belarusian).

2. Poluyan V., Poluyan I. Revolutsionnoye $i$ natsional'no-osvoboditel'noye dvizheniye $v$ Zapadnoy Belorussii v 1920-1939 gg. [The revolutionary and national liberation movement in Western Belarus in 1920-1939]. Minsk, Gosizdat BSSR Publ., 1962. 224 p.

3. Holzer J. Mozaika polityczna Drugiej Rzeczypospolitej [Political mosaic of the Second Polish Republic]. Warszawa, Książka i Wiedza Publ., 1974. 664 p.

4. Gomółka K. Belarusians in the Second Polish Republic. Zeszyty naukowe Politechniki Gdańskiej. Ekonomia [Scientific journals of the Gdańsk University of Technology. Economy], 1992, no. XXXI, pp. 3-179 (In Poland). 
5. Muller D., Harre A. Introduction: Agrarianism as Third Way. Transforming rural societies. Innsbruck, Studienverlag, 2011, pp. 7-13 (In English).

6. Karotki narys belaruskaga pytannya [A short essay on the Belarusian question]. Minsk, Logvinau Publ., 2009. 396 p.

7. From the editors. Syalyanskaya niva [Peasant field], 1925, no. 1. P. 1.

8. From the organizational life of the Belarusian Peasants' Union. Syalyanskaya niva [Peasant field], 1926, no. 11. P. 2 (In Belarusian).

9. Bildziukievich A. Conference of the Belarusian Peasants' Union. Syalyanskaya niva [Peasant field], 1926, no. 14. P. 2 (In Belarusian).

10. Pragrama i statut Belaruskaga syalyanskaga sayuza [Program and charter of the Belarusian Peasants' Union]. Vil'nya, N. Levin Publ., 1926. 16 p.

11. Report from the conference of the Belarusian Peasants' Union. Syalyanskaya niva [Peasant field], 1927, no. 58. pp. 1-2 (In Belarusian).

12. Central State Archives of Lithuania (CSAL). Fund 15. Ap. 2. B. 386.

13. Defeat of Polish policy in Western Belarus (election results in Vilnius voivodeship). Savetskaya Belarus' [Soviet Belarus], 1927, no. 183. P. 2 (In Belarusian).

14. Pashkievich A. V. Parlamentskiya formy zmagannya za natsyyanal'nyya i satsyyal'nyya pravy belaruskaga naroda u mizhvayennay Pol'shchy (1921-1930 gg.). Dys. kand. gist. navuk [Parliamentary forms of struggle for national and social rights of the Belarusian people in interwar Poland (1921-1930). PhD Diss.]. Minsk, 2006. 162 p.

15. State Archives of Hrodna Region (SAHR). Fund 551. L. 1. F. 1028.

16. Bazarevich G. Kh. Belarusian cultural and educational movement in the Braslav region in 1925-1930. Braslauskiya chytanni [Braslav readings]. Minsk, Belaruskaya navuka Publ., 2016, pp. 208-217 (In Belarusian).

17. Nadniomaniec. An activist of the Peasants' Union. Nash golas [Our voice], 1927, no. 3. P. 4 (In Belarusian).

18. Belarusians. Sprawy Narodowościowe [National Affairs], 1927, no. 3, pp. 283-288 (In Poland).

19. CSAL. Fund 53. Ap. 23. B. 1784.

20. State Archives of Brest Region (SABR). Fund 67. L. 1. F. 1232.

\section{Інфармацыя пра аўтара}

Горны Аляксандр Сяргеевіч - кандыдат гістарычных навук, дацэнт, дацэнт кафедры гісторыі Беларусі, археалогіi і спецыяльных гістарычных дысцыплін. Гродзенскі дзяржаўны ўніверсітэт імя Янкі Купалы (230023, г. Гродна, вул. Ажэшка, 22, Рэспубліка Беларусь). E-mail: litvin.gorny@gmail.com

\section{Information about the author}

Gorny Aliaksandr Syargeyevich - PhD (History), Associate Professor, Assistant Professor, the Department of History of Belarus, Archeology and Special Historical Disciplines. Yanka Kupala State University of Grodno (22, Azheshka str., 230023, Grodno, Republic of Belarus). Email: litvin.gorny@gmail.com 